\title{
Humic substances isolated from residues of sugar cane industry as root growth promoter
}

\author{
Jader Galba Busato ${ }^{1}$; Daniel Basílio Zandonadi²; Leonardo Barros Dobbss ${ }^{1}$; Arnoldo Rocha \\ Façanha $^{2}$; Luciano Pasqualoto Canellas ${ }^{1 *}$ \\ ${ }^{1}$ UENF/CCTA - Lab. Solos, Av. Alberto Lamego, 2000 - 28013-603 - Campos dos Goytacazes, RJ - Brasil. \\ ${ }^{2}$ UENF/CBCT - Lab. Biologia Celular e Tecidual. \\ *Corresponding author < canellas@uenf.br>
}

\begin{abstract}
Plant growth promoting substances are widely used in modern agriculture. Several products in the market are humic substances isolated from different sources. The filter cake, a residue of sugar production, is a rich and renewable source of organic matter and these characteristics place the filter cake as a possible source of plant growth promoting substances. Humic acids (HA) from filter cake were characterized, and their effects as root growth promoters were evaluated. Chemical features of the HA were evaluated through elemental composition, acidic functional groups, $\mathrm{E}_{4} / \mathrm{E}_{6}$ ratio and infrared spectroscopy analyzes. The biological activity of the HA was assessed using root architecture parameters and the P-type $\mathrm{H}^{+}$-ATPase activity. The lateral root development was directly related to the stimulation of plasma membrane ATPase activity. The ability of HA to promote root development indicate that HA from filter cake can be used as environmental plant growth stimulators.

Key words: $\mathrm{H}^{+}$-ATPase, Brazil, industrial residues, physiological effects, bioactivity
\end{abstract}

\section{Substâncias húmicas isoladas de resíduos da indústria da cana-de-açúcar como promotoras de crescimento radicular}

\begin{abstract}
RESUMO: Substâncias promotoras do crescimento vegetal são amplamente utilizadas na agricultura moderna. Existem vários produtos no mercado, muitos dos quais são substâncias húmicas isoladas de diferentes fontes. A torta de filtro, um resíduo da produção do açúcar, é uma fonte rica e renovável de matéria orgânica e essas características a tornam uma possível fonte de substâncias promotoras do crescimento vegetal. Ácidos húmicos $(\mathrm{AH})$ da torta de filtro foram caracterizados, e foi avaliado seu efeito como promotor de crescimento radicular. As características químicas dos $\mathrm{AH}$ foram avaliadas por meio da composição elementar, grupos funcionais ácidos, relação $\mathrm{E}_{4} / \mathrm{E}_{6}$ e espectroscopia de infravermelho. A atividade biológica dos $\mathrm{AH}$ foi acessada avaliando-se a arquitetura radicular e a atividade da $\mathrm{H}^{+}$-ATPase de membrana plasmática. O desenvolvimento de raízes laterais foi diretamente relacionado ao estímulo da atividade $\mathrm{da} \mathrm{H}^{+}$-ATPase. A habilidade dos $\mathrm{AH}$ em promover o desenvolvimento radicular indica que $\mathrm{AH}$ extraídos da torta de filtro podem ser utilizados como estimuladores do crescimento de plantas.
\end{abstract}

Palavras-chave: $\mathrm{H}^{+}$-ATPase, Brasil, resíduos industriais, efeitos fisiológicos, bioatividade

\section{Introduction}

The agricultural landscape in the North of Rio de Janeiro State in Brazil is dominated by sugar cane farming. This crop occupies almost 70,000 ha in the Campos dos Goytacazes region (Veiga et al., 2006) and almost the entire sugar cane production is processed in the local industrial units. Besides sugar and alcohol, these units also produce an important amount of residues. Among the residues, the filter cake has an important role due to its nutrient composition (Demattê et al., 2005) and high organic matter content, around 48\% (Meunchang et al., 2005). These characteristics place the filter cake as a possible source of plant growth promoting substances.

Plant growth promoting substances are widely used in modern agriculture. There are several plant growth products in the market, many of which are humic substances (HS) isolated from different sources. Major attention has been directed to HS isolated from vermicompost (Atiyeh et al., 2002; Canellas et al., 2002; Rodda et al., 2006; Zandonadi et al., 2007) or sewage sludge (Façanha et al., 2002; Zandonadi et al., 2007). The use of others organic residues (i.e. filter cake) is less known, although it could also represent an important alternative as low cost and rich input to plant development.

The HS affect plant physiology, with emphasis on root development (Vaughan and Malcolm, 1985). Canellas et al. (2002) showed that humic acids (HA) isolated from earthworm compost can enhance lateral root development along with phosphohydrolytic activity of plasma membrane $\mathrm{H}^{+}$-ATPase. HA isolated from different sources and auxins regulate not only the plasma membrane, but also the tonoplast proton pumps, resulting in maize root development (Zandonadi et al., 2007). These membrane enzymes generate the electrochemical potential and the necessary energy for nutrient uptake and cell growth (Sze et al., 1999). 
The aims of this work were to characterize the HA isolated from filter cake and evaluate their potential as root growth promoting substances in maize (Zea mays L.).

\section{Material and Methods}

Filter cake - It is the pulp resulting from the grinding of sugar cane. Briefly, the sugar cane juice receives sulfur and calcium to clean and to promote colloids' flocculation, respectively. The resulting colorless and cleaned juice is evaporated and the broth goes to vacuum filtration. The remaining solid stacked in the filter is called filter cake. The filter cake from 2004/2005 harvest was sampled in 2006, in Campos dos Goytacazes (21 ${ }^{\circ} 45^{\prime} 14^{\prime \prime} \mathrm{S}$ and $\left.41^{\circ} 19^{\prime} 26^{\prime \prime} \mathrm{W}\right)$, northern Rio de Janeiro State, Brazil. Filter cake was collected after one year exposure to the environmental conditions. The residue was air-dried and analyzed according to EMBRAPA (1997). Briefly, the $\mathrm{pH}$ was measured in water (soil:solution relationship equal 1:2.5); the $\mathrm{P}$ and $\mathrm{K}$ contents were extracted by Mehlich 1 solution; $\mathrm{Ca}, \mathrm{Mg}$ and Al by $\mathrm{KCl} 1 \mathrm{~mol} \mathrm{~L}^{-1}$; $\mathrm{S}$ was obtained by the turbidimetric method and $\mathrm{H}^{+}$by determination using calcium acetate buffered to $\mathrm{pH}$ 8.0.

Isolation and Chemical Characterization of $\mathrm{HA}$ - A composite sample of this cake was used for organic matter fractionation and HA extraction in order to perform a spectroscopic and biological characterization. Briefly, HA were extracted as follows: 10 volumes of $0.5 \mathrm{~mol} \mathrm{~L}^{-1}$ $\mathrm{NaOH}$ were mixed with 1 volume of filter cake, under $\mathrm{N}_{2}$ atmosphere. After $12 \mathrm{~h}$, the suspension was centrifuged at 5,000 $\mathrm{x} g$ and acidified to $\mathrm{pH} 1.5$ using $6 \mathrm{~mol} \mathrm{~L}^{-1}$ $\mathrm{HCl}$. The solubilization and precipitation of $\mathrm{HA}$ were repeated three times and the last pellet was mixed with 10 volumes of a diluted mixture of $\mathrm{HF}-\mathrm{HCl}$ solution (prepared with $5 \mathrm{~mL}$ of concentrated $\mathrm{HCl}$ and $5 \mathrm{~mL}$ of concentrated $\mathrm{HF}$, diluted to $1 \mathrm{~L}$ with distilled water). After centrifugation $(5,000 \mathrm{xg})$ for $15 \mathrm{~min}$, the sample was repeatedly washed with distilled water until a negative test against chloride $\left(\mathrm{Cl}^{-}\right)$using $\mathrm{AgNO}_{3}$ is achieved; afterwards, the sample is dialyzed against distilled water using a 12 to $14-\mathrm{kD}$ cutoff membrane. The dialyzate was lyophilized and chemically characterized. Then, the HA powder was solubilized with 50 to $100 \mathrm{~mL}$ of $0.05 \mathrm{~mol}$ $\mathrm{L}^{-1} \mathrm{NaOH}$ and the $\mathrm{pH}$ was adjusted to 5.5 with $0.1 \mathrm{~mol}$ $\mathrm{L}^{-1} \mathrm{HCl}$.

The carbon content in all humified fractions (humic acids, fulvic acids and humin) was determined by dicromatometry through colorimetric procedures on a Shimadzu spectrophotometer at $600 \mathrm{~nm}$ (Anderson and Ingram, 1993). After the extraction and purification of HA, its elemental composition was determined using a CHN Perkin-Elmer autoanalyzer. The total acidity $\left[\mathrm{Ba}(\mathrm{OH})_{2}\right.$ method $]$ and the carboxylic acidity $\left[\mathrm{Ca}(\mathrm{Oac})_{2}\right.$ method] of HA were determined according to Schnitzer and Gupta (1965) followed by a potentiometric titration. The phenolic acidity was obtained by difference.

\section{Spectroscopic Analyzes}

$\mathrm{E}_{4} / \mathrm{E}_{6}$ Ratio $-\mathrm{E}_{4} / \mathrm{E}_{6}$ ratios were determined dissolving 4 $\mathrm{mg}$ of $\mathrm{HA}$ in $10 \mathrm{~mL}$ of $0.05 \mathrm{~mol} \mathrm{~L}^{-1} \mathrm{NaHCO}_{3}$ and adjusting the $\mathrm{pH}$ to 8.3 with diluted $\mathrm{NaOH}$ (Kononova, 1961). The absorbances at $465 \mathrm{~nm}$ and $665 \mathrm{~nm}$ were measured on a Hitashi U2000 spectrophotometer. The ratio of the absorbance values gave the $\mathrm{E}_{4} / \mathrm{E}_{6}$ ratio.

Fourier Transform Infrared Spectroscopy (FTIR) FTIR spectra of $\mathrm{HA}$ were recorded on $\mathrm{KBr}$ pellets in the $400-4000 \mathrm{~cm}^{-1}$ wave number using a Shimadzu 83000 spectrophotometer. A mixture of $1 \mathrm{mg} \mathrm{HA}$ and $300 \mathrm{mg}$ $\mathrm{KBr}$ was pressed, under reduced pressure, to obtain the $\mathrm{KBr}$ pellets. The procedure was repeated three times for each sample. The spectra subtraction procedure was used to infer the $\mathrm{H}_{2} \mathrm{O}$ and $\mathrm{CO}_{2}$ contaminations (absorption region at $3300-3400 \mathrm{~cm}^{-1}$ and $2330-2350 \mathrm{~cm}^{-1}$, respectively).

\section{Humic Acids Bioactivity}

Plant Growth and Humic Acids Treatment - Maize seeds (Zea mays L.) were cleaned soaking them in $0.5 \%$ $\mathrm{NaClO}$ for $30 \mathrm{~min}$, then rinsing and soaking them in water for $6 \mathrm{~h}$. Afterwards, the seeds were sown on wet filter paper and germinated in the dark at $28^{\circ} \mathrm{C}$. Fourday-old maize seedlings, with roots of about $3 \mathrm{~cm}$, were transferred to a solution containing $0.002 \mathrm{~mol} \mathrm{~L}^{-1}$ $\mathrm{CaCl}_{2}$ and supplemented with $0,4,40$ and $400 \mathrm{mg} \mathrm{L}^{-1}$ $\mathrm{HA}$ extracted from filter cake. The $\mathrm{pH}$ of the system was adjusted to 6.0 using $\mathrm{NaOH}$ and/or $\mathrm{HCl} 0.01 \mathrm{~mol}$ $\mathrm{L}^{-1}$ in all treatments. After seven days, one sample of plant roots was harvested to evaluate their growth, while another sample was collected for cellular fractionation. Further biochemical assays were performed to analyze the plasma membrane $\mathrm{H}^{+}$-ATPase hydrolytic activity.

Measurements of Root Growth and Lateral Root Development - On the $7^{\text {th }}$ day of HA treatment, roots were collected to estimate their surface area using DeltaTscan ${ }^{\mathrm{TM}}$ (Dynamax Inc.) image analyzer software. All roots of treated seedlings were harvested to evaluate the number of mitotic sites and emergence of lateral roots, as described in Canellas et al. (2002). Roots were washed in water and cleared heating at $75^{\circ} \mathrm{C}$ for $20 \mathrm{~min}$ in $\mathrm{KOH}(0.5 \%, \mathrm{w} / \mathrm{v})$. Afterwards, the roots were rinsed in water and stained for $14 \mathrm{~h}$ in the dark with hematoxylin staining solution; rinsed once again in water and destained in $80 \%$ lactic acid at $75^{\circ} \mathrm{C}$ for $30-90$ s. Individual samples were observed using stereoscopic microscopy at $40 \mathrm{x}$ to evaluate the number of mitotic sites, visible as red dots on a pink to white background of root tissue. Fresh root weight was also measured and another sample of seedlings roots were collected and used for further experiments.

Microsomal Isolation - Microsomal vesicles were isolated from roots grown with and without $40 \mathrm{mg} \mathrm{L}^{-1} \mathrm{HA}$ using differential centrifugation as described by De 
Michelis and Spanswick (1986), with some modifications (Façanha and De Meis, 1995). About $15 \mathrm{~g}$ (fresh weight) of maize roots were homogenized using a mortar and pestle in $30 \mathrm{~mL}$ of ice-cold buffer containing $0.25 \mathrm{~mol} \mathrm{~L}^{-1}$ sucrose, $10 \%(\mathrm{w} / \mathrm{v})$ glycerol, $0.5 \%(\mathrm{w} / \mathrm{v})$ polyvinylpyrrolidone-40 (40 kD), $0.002 \mathrm{~mol} \mathrm{~L}^{-1} \mathrm{EDTA}, 0.5 \%(\mathrm{w} / \mathrm{v})$ bovine serum albumin and $0.001 \mathrm{~mol} \mathrm{~L}^{-1}$ Tris- $\mathrm{HCl}$ buffer, $\mathrm{pH}$ 8.0. Just before use, $0.15 \mathrm{~mol} \mathrm{~L}^{-1} \mathrm{KCl}, 0.002 \mathrm{~mol} \mathrm{~L}^{-1}$ dithiothreitol (DTT), and $0.001 \mathrm{~mol} \mathrm{~L}^{-1}$ phenylmethylsulfonyl fluoride were added to the buffer. The homogenate was strained through four layers of cheesecloth and centrifuged at $8,000 \mathrm{xg}$ for $10 \mathrm{~min}$. The supernatant was centrifuged once more at $8,000 \times g$ for $10 \mathrm{~min}$ and then at $100,000 \mathrm{x} g$ for $40 \mathrm{~min}$. The pellet was resuspended in a small volume of ice-cold buffer containing $0.01 \mathrm{~mol} \mathrm{~L}^{-1}$ Tris- $\mathrm{HCl}(\mathrm{pH} 7.6), 10 \%(\mathrm{v} / \mathrm{v})$ glycerol, $0.001 \mathrm{~mol} \mathrm{~L}^{-1}$ DTT and $0.001 \mathrm{~mol} \mathrm{~L}^{-1}$ EDTA. The vesicles were either used immediately or frozen under liquid $\mathrm{N}_{2}$ and stored at $-70^{\circ} \mathrm{C}$ until use. Protein concentration was determined by the method of Bradford (1976).

Plasma Membrane (PM) $\mathrm{H}^{+}$-ATPase Activity - The $\mathrm{H}^{+}$-ATPase activity in the total membrane fraction was determined measuring the release of inorganic Phosphorous colorimetrically (Fiske and Subbarow, 1925). Between $60 \%$ and $75 \%$ of the ATPase activity in the microsomal vesicle measured at $\mathrm{pH} 6.5$ was inhibited by vanadate $\left(5 \times 10^{-5} \mathrm{~mol} \mathrm{~L}^{-1}\right)$. Vanadate is a very effective inhibitor of the plasma membrane P-type $\mathrm{H}^{+}$-ATPase (Sze, 1985). In all experiments, the ATPase activity was measured at $35^{\circ} \mathrm{C}$, with and without vanadate, and the difference between these two activities was attributed to the $\mathrm{PM} \mathrm{H}^{+}$-ATPase.

Statistical Analyzes - The root development parameters were evaluated by the variance between groups using Tukey test $(p<0.05)$ for means. The PM H$H^{+}$-ATPase activity corresponds to representative data from three independent vesicles isolation experiments \pm standard deviation (SE).

\section{Results and Discussion}

The high nutrient content of the filter cake, mainly calcium $\left(203.5 \mathrm{mmol} \mathrm{kg}^{-1}\right)$ and sulfur $\left(9.8 \mathrm{mmol}_{\mathrm{c}} \mathrm{kg}^{-1}\right)$, occurs as a result of the process of removing floating solids. The absence of aluminum, the high phosphorous content $\left(0.73 \mathrm{~g} \mathrm{~kg}^{-1}\right)$ and the weak acidity ( $\mathrm{pH}$ 6.0) allow the use of this residue as a soil amendment. Moreover, the filter cake promotes optimum chemical conditions for organic matter stabilization. In fact, the high total carbon content $\left(489.7 \mathrm{~g} \mathrm{~kg}^{-1}\right)$ goes along with low C/N ratio (11.9) and high carbon in the HA form $\left(132.8 \mathrm{~g} \mathrm{~kg}^{-1}\right)$. The filter cake is characterized by a high content of carbon in the humin fraction $\left(320.0 \mathrm{~g} \mathrm{~kg}^{-1}\right)$ and ratio between $\mathrm{HA}$ and fulvic acids (FA), $\left(\mathrm{C}_{\mathrm{HA}} / \mathrm{C}_{\mathrm{FA}}\right)$ close to 5.5 ; therefore, the filter cake is a source of soluble humic substances with high hydrophobic carbon content (Camargo et al., 1999).

One of the characteristics of the organic matter stabilization is the increasing of HA, which are associations of heterogeneous molecules stabilized by hydrophobic interactions into only apparently high molecular weight sizes (Piccolo et al., 1996). These hydrophobic interactions seem to be the main cause of the bioresistance of HS (Piccolo, 2002). In this way, it is possible to check the residue maturation by the distribution of the humified fractions. At the initial stage, the HA content is lower than that observed at the end of the humification process (Meunchang et al., 2005). The resulting HA content in the filter cake is higher compared to other organic residues used as fertilizers, such as composts of sewage sludge and municipal waste (Canellas et al., 2001). The prevalence of the more stable fraction (e.g., HA) in the humified organic matter of filter cake indicates that it is suitable as a source for extraction of HS.

The elemental composition, ash free, is shown in Table 1. The results showed low $\mathrm{C}$ and $\mathrm{N}$ contents and the high $\mathrm{O}$ content, compared to the average composition - $\mathrm{C}\left(551 \mathrm{~g} \mathrm{~kg}^{-1}\right), \mathrm{H}\left(58 \mathrm{~g} \mathrm{~kg}^{-1}\right), \mathrm{N}\left(35 \mathrm{~g} \mathrm{~kg}^{-1}\right)$ and $\mathrm{O}$ $\left(356 \mathrm{~g} \mathrm{~kg}^{-1}\right)$ - usually found in HA extracted from soil (Rice and MacCarthy, 1991). The high $O$ content suggests an elevated oxidation level of HA, suggesting a high HA total acidity or cation exchange capacity. Indeed, the investigation of the acidic functional groups reveals the presence of high total acidity (Table 1). Moreover, it is interesting to note the similar contents of the more acidic groups $(\mathrm{COOH})$ and weakly acidic groups $(\mathrm{OH})$. This balance in the acidic groups of HA indicates a dissociation capacity in a broad range of $\mathrm{pH}$ from 3.5 to 6.0 to more acidic groups, and above 7.0 to phenolic compounds (Plaza et al., 2005).

Table 1 - Elemental composition, atomic ratio, acidity and $\mathrm{E}_{4} / \mathrm{E}_{6}$ ratio of humic acids isolated from filter cake of sugar cane plants.

\begin{tabular}{|c|c|c|c|c|c|c|c|c|c|c|}
\hline \multicolumn{4}{|c|}{ Elemental composition } & \multicolumn{3}{|c|}{ Atomic ratio } & \multicolumn{3}{|c|}{ Acidity } & \multirow{2}{*}{$\begin{array}{c}\mathrm{E}_{4} / \mathrm{E}_{6} \text { ratio } \\
-\end{array}$} \\
\hline C & $\mathrm{H}$ & $\mathrm{N}$ & $\mathrm{O}$ & $\mathrm{C} / \mathrm{N}$ & $\mathrm{H} / \mathrm{C}$ & $\mathrm{O} / \mathrm{C}$ & Total & $\mathrm{COOH}$ & $\mathrm{PhOH}$ & \\
\hline-3 & $\mathrm{~g}$ & 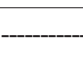 & -3 & & & & 3 & $\mathrm{cmol}_{\mathrm{c}} \mathrm{kg}^{-1}$ & 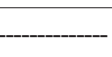 & \\
\hline 465.7 & 57.2 & 29.9 & 451.7 & $18.17 \mathrm{a}$ & $1.47 \mathrm{a}$ & $0.73 a$ & 745 & 351 & 394 & 3.47 \\
\hline $407-587^{\mathrm{b}}$ & $32-62^{b}$ & $8-43^{b}$ & $328-383^{\mathrm{b}}$ & $19.49^{\mathrm{b}, \mathrm{c}}$ & $0.10^{\mathrm{b}, \mathrm{c}}$ & $0.72^{b, c}$ & $500^{d}$ & $320^{d}$ & $178^{\mathrm{d}}$ & $<6^{e}$ \\
\hline
\end{tabular}

${ }^{a}$ Atomic ratio between elements. ${ }^{b}$ Usual range for the elemental composition of humic acids according to Stevenson (1994). ${ }^{c}$ Average values for atomic rations according to Stevenson (1994). ${ }^{\mathrm{d}}$ Average values for humic acids from different soils according to Griffth and Schnitzer (1975) and Celi et al. (1997). ${ }^{\mathrm{e} C h e n ~ e t ~ a l . ~(1977) . ~}$ 
The HA isolated from filter cake can be characterized by the relatively low $\mathrm{H} / \mathrm{C}$ atomic ratio. This ratio is an indirect measurement of the unsaturation level (Stevenson, 1994). In other words, this is a ratio of the alkyl $\mathrm{C}$ and the conjugated $\mathrm{C}$ linked to aromatic systems (Rice and MacCarthy, 1991). HA isolated from other organic residues such as urban waste compost (Campitelli et al., 2006) and sewage sludge (Canellas et al., 2001) usually exhibit higher $\mathrm{H} / \mathrm{C}$ ratio. Besides many studies, the process of organic matter stabilization still remains unclear (Saiz-Jimenez et al., 2006). Despite that, many authors believe that the chemical and biochemical reactions that occur during humification transform the organic matter through stabilization of aromatic structures, leading to a relative enrichment of aromatic carbon and selective preservation of alkyl carbon of soil biopolymers resistant to decomposition, such as cutins and suberins (Zech et al., 1997). Thus, the net result of this process is an enrichment of aromatic carbon and a drop in $\mathrm{H} / \mathrm{C}$ ratio.

The ratio between the absorbance at 465 and $665 \mathrm{~nm}$ $\left(\mathrm{E}_{4} / \mathrm{E}_{6}\right)$ have proven to be qualitatively related, to a certain extent, to some structural features of HS (Chen et al., 1977; Stevenson, 1994). The $\mathrm{E}_{4} / \mathrm{E}_{6}$ ratio of the HA isolated from filter cake is low (3.47), see Table 1, when compared to HA from soils. For example, Canellas et al. (2004) studied an Ultisol covered with different plants and the values found for $\mathrm{E}_{4} / \mathrm{E}_{6}$ were among 6.2 and 8.3. The value found for the HA from filter cake suggest a relatively high degree of aromaticity and/or high molecular weight/size.

The first indirect evaluation of HA aromaticity via the $\mathrm{E}_{4} / \mathrm{E}_{6}$ ratio was undertaken by Kononova (1961), who collected data from several HA isolated from many different soils and showed an inverse relationship between the soil fertility and the $\mathrm{E}_{4} / \mathrm{E}_{6}$ number. Consequently, the condensation reactions of organic matter could be easily evaluated through this parameter, since, in theory, as aromaticity rises together with the humification, so the $\mathrm{E}$ / $\mathrm{E}_{6}$ ratio drops. Despite the controversies concerning the $\mathrm{E}_{4} / \mathrm{E}_{6}$ ratio as an indicator of aromaticity degree, this technique is still widely used. It was reported that the $\mathrm{E}_{4} / \mathrm{E}_{6}$ ratio is mainly related to the size of the humic substances (Chen et al., 1977). The NMR CP/MAS ${ }^{13} \mathrm{C}$ techniques with polar dephashing (DD) measurements of condensed aromatic or substituted carbons demonstrated a negative significant correlation $\left(\mathrm{R}^{2}=0.94\right)$ with the $\mathrm{E}_{4} / \mathrm{E}_{6}$ ratio, indicating that this ratio identifies the degree of condensation of aromatic rings (Saab and Martin-Neto, 2007).

The functional groups of chemical substances can be analyzed through the Fourier Transform Infrared (FTIR) spectroscopy, which provides information about the stretching and deformation vibrations of chemical bonds between atoms showing an electric dipole moment characterized by non-zero value (Colthup et al., 1964). The FTIR spectrum of the filter cake HA (Figure 1) demonstrates the typical profile of weak and polyprotic organic acids (Colthup et al., 1964). The HA spectrum shows six

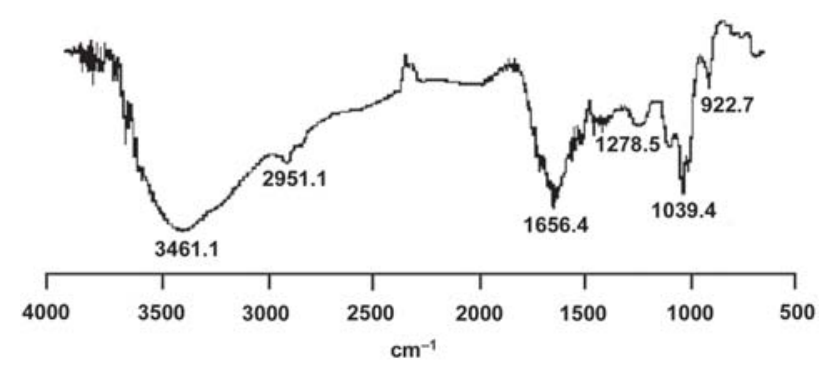

Figure 1 - FTIR spectrum of humic acids isolated from filter cake.

major absorption bands in according to works by Colthup et al. (1964), Bloom and Leenheer (1989) and Stevenson (1994). The intense and broad absorption band at $3461 \mathrm{~cm}^{-1}$ is due to $\mathrm{OH}$ bonds stretching in hydroxyl groups which mainly belong to carboxyl acids linked to hydrogen which can modify the stretching frequency. The well-defined and sharp band at $2951 \mathrm{~cm}^{-1}$ is due to symmetric stretching of $\mathrm{CH}$ bonds, mainly belonging to methyl groups $\left(\mathrm{CH}_{3}\right)$. The broad absorption band at $1656 \mathrm{~cm}^{-1}$ is due to several symmetric stretching of $\mathrm{C}=\mathrm{O}$ bonds of $\mathrm{COO}^{-}$groups in amide II and quinines. The broad absorption band at $1278.5 \mathrm{~cm}^{-1}$ is due to $\mathrm{OH}$ deformation in carboxyl groups, ester and phenolic bonds. The absorption band at $1039 \mathrm{~cm}^{-1}$ is due to C-O stretching of polysaccharides. Finally, the absorption band at $923 \mathrm{~cm}^{-1}$ is due to vibrational modes of $\mathrm{C}-\mathrm{H}$ bonds in aromatic groups and inorganic and organic/metalic impurity. The obtained FTIR spectrum is very similar to that from soil HA. Thanks to FTIR, it is possible to differentiate the source and the humification condition of the organic matter (Stevenson, 1994). The HS with relatively low humification degree, such as FA, has a spectrum without $\mathrm{CH}_{3}, \mathrm{CH}_{2}$ and $\mathrm{CH}$ absorption bands (generally located around $2900-2850 \mathrm{~cm}^{-1}$ ). Moreover, the presence of a wide and diffuse absorption band at 1100 $\mathrm{cm}^{-1}$ is characteristic of low-humified HS; in fact, the band is related to C-O stretching of polysaccharides. The HS in the initial humification degree has a relatively high content of preserved sugars arisen from degradation reactions (Baes and Bloom, 1989). Therefore, it is tempting to speculate a structural similarity of HA isolated from filter cake to HA from soils.

The soil quality and productive capacity are often related to the organic matter content, which is widely known as a plant growth regulator (O'Donnell, 1973; Vaughan and Malcolm, 1985; Atiyeh et al., 2002). The biochemical and molecular mechanisms associated with this process are still to be elucidated. A mechanism based on plant energetic regulation through the modulation of the plant proton pumps has been proposed (Canellas et al., 2002; Zandonadi et al., 2007). The plasma membrane $\mathrm{H}^{+}$-ATPase of plant cells is an electrogenic proton pump, which plays important bioenergetic and regulatory roles in plant cell physiology (Serrano, 1989).

The exposure to HA affects the growth of maize seedlings (Table 2). HA isolated from filter cake are able to modify root development in a dose-dependent way (Fig- 
Table 2 - Effect of different concentrations of humic acids isolated from filter cake on maize root development and on plasma membrane (PM) $\mathrm{H}^{+}$-ATPase activity from root-isolated vesicles of seedlings grown for 7 days in minimal solution $\left(0.002 \mathrm{~mol} \mathrm{~L}^{-1} \mathrm{CaCl}_{2}\right)$.

\begin{tabular}{|c|c|c|c|c|c|c|c|}
\hline Concentration & Area & Length & Dry weight & Lateral roots & Mitotic sites & Root/shoot ratio & PM H+ATPase \\
\hline mg HA L ${ }^{-1}$ & 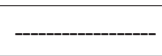 & \% + & g & Nur & nber - & & $\mu \mathrm{mol}$ Pi mg $\operatorname{Ptn}^{-1} \mathrm{~min}^{-}$ \\
\hline 0 & $100 \pm 10 b$ & $100 \pm 09 b$ & $0.027 \pm 0.008 b$ & $77 \pm 14 a b$ & $26 \pm 05 b$ & $0.58 \mathrm{~b}$ & $0.83^{*} \pm 0.05(100 \%)$ \\
\hline 4 & $203 \pm 43 b$ & $157 \pm 10 b$ & $0.048 \pm 0.020 \mathrm{ab}$ & $46 \pm 11 b$ & $30 \pm 09 b$ & $1.02 \mathrm{a}$ & $0.94 * \pm 0.02(113 \%)$ \\
\hline 40 & $325 \pm 31 a$ & $232 \pm 13 a$ & $0.054 \pm 0.010 a$ & $84 \pm 14 a$ & $68 \pm 10 a$ & 0.82 a & $1.70 * \pm 0.05(205 \%)$ \\
\hline 400 & $311 \pm 32 \mathrm{a}$ & $233 \pm 08 \mathrm{a}$ & $0.053 \pm 0.012 a$ & $69 \pm 10 \mathrm{ab}$ & $27 \pm 03 b$ & $0.86 \mathrm{a}$ & $1.12 * \pm 0.14(135 \%)$ \\
\hline
\end{tabular}

Data represent means from three independent experiments performed with ten maize seedlings per treatment. Different letters in collums indicate statistical differences (Tukey test $p<0.05$ ). "Values represents the means \pm SE of representative data of three independent experiments.

ure 2). One similar curve was showed for lateral root density of Arabidopsis treated with HA isolated from Oxisols (Dobbss et al., 2007). The authors also found that inhibition concentration varies from 250 to $400 \mathrm{mg} \mathrm{L}^{-1}$. The HA dose response curve of $\mathrm{H}^{+}$-ATPase activity was already shown as comparable to typical phytohormone assays (Zandonadi et al., 2007). The mechanism through which HA can regulate the plasma membrane $\mathrm{H}^{+}$-ATPase activity (Canellas et al., 2002) appears to be similar to that proposed for auxins, where it was shown that indole-3-acetic acid (IAA) rapidly increases the amount of antibody-detectable $\mathrm{H}^{+}$-ATPases in the plasma membrane (Hager et al., 1991). Indeed, the mRNA of the major isoform of the plasma membrane $\mathrm{H}^{+}$-ATPase (MHA2) was induced three-fold in maize coleoptiles treated with auxin (Frías et al., 1996). In addition to the detection of the auxin molecules in the HS structure (Canellas et al., 2002; Quaggiotti et al., 2004), the MHA2 mRNA levels was enhanced by the HS treatment in maize seedlings (Quaggiotti et al., 2004).

The induction of mitotic sites in maize roots treated with $40 \mathrm{mg} \mathrm{L}^{-1} \mathrm{HA}$, isolated from filter cake (Table 2), occurs similar to that found with HA isolated from earthworm compost (Canellas et al., 2002) and other organic matter sources (Zandonadi et al., 2007). The root growth stimulation is confirmed by the digital analyzes of plant root surface area. The HA doses of 4,40 and $400 \mathrm{mg} \mathrm{L}^{-1}$ enhanced the surface area $103 \%, 225 \%$ and $211 \%$, respectively. In agreement with other works (Canellas et al., 2002; Zandonadi et al., 2007), this increase seems to be related to the plasma membrane $\mathrm{H}^{+}$-ATPase activation. These authors also found that the maize rooting enhancement could vary from $50 \%$ to $1000 \%$ depending on the HA source. In the present study, the induction of root mitotic sites results in a lateral root development in a $\mathrm{H}^{+}$-ATPase dependent way (Figure 2; $\mathrm{R}=1.00$ ). The root dry weight is increased by $90 \%$ on average under HA treatment. The stimulation of the primary root length was $57 \%, 132 \%$ and $133 \%$ under 4,40 and $400 \mathrm{mg}$ $\mathrm{L}^{-1}$ of HA. Vaughan (1974) showed that the length of cuttings of pea plants treated with $50 \mathrm{mg} \mathrm{L}^{-1} \mathrm{HA}$ isolated from soil increased $146 \%$ relative to controls. Malik and Azam (1985) showed that $36 \mathrm{mg} \mathrm{L}^{-1} \mathrm{HA}$, extracted from soils, enhanced wheat root length by $321 \%$.

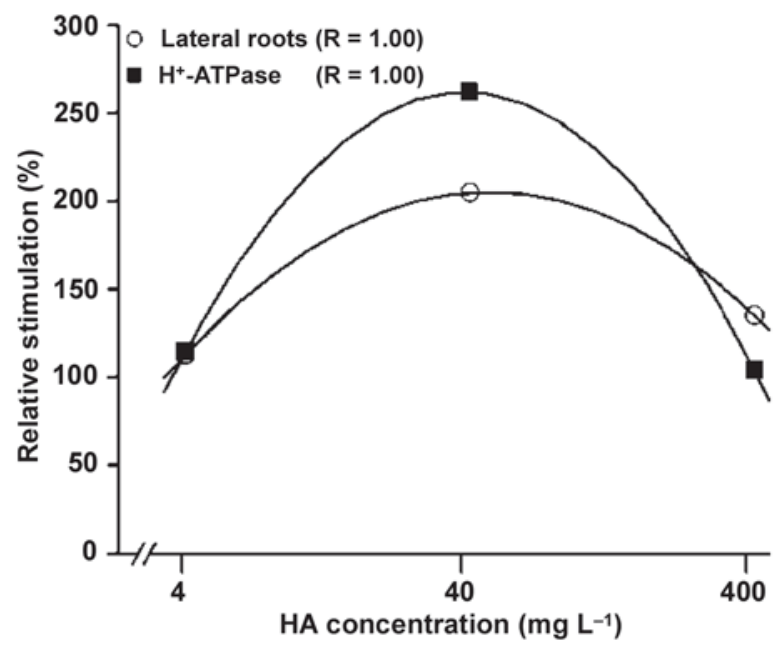

Figure 2 - Relative stimulation of hydrolytic activity of the vanadate-sensitive $\mathrm{H}^{+}$-ATPase of plasma membrane in-side-out vesicles isolated (close square) and number of lateral root emergence (open circles) from maize roots, as a function of humic acids (HA) concentration over control (100\%). Polynomial fit was calculated from the data and logarithmrepresented in logarithm scale.

The magnitude of HA stimulation on plant growth may vary due to the complex and heterogeneous intrinsic features of each HA. The high $\mathrm{C}_{\mathrm{HA}} / \mathrm{C}_{\mathrm{FA}}$ ratio value (5.5) indicates the concentration of hydrophobic compounds. It is postulated that associations of non-polar molecules, derived from plant degradation and microbial activity, incorporate more polar molecules, thereby preventing their otherwise rapid microbial degradation and enhancing their persistence. As the hydrophobicity of organic matter enhance the organic carbon sequestration (Spaccini et al., 2002), the soil stability (Piccolo and Mbagwu, 1999; Capriel et al., 1990; Mbagwu and Piccolo, 1998) and the soil fertility (Canellas et al., 2007). The hydrophobicity was found to be the basis of chemical stability of HA (Piccolo, 2002).

In summary, the results of this study suggest that due to the high availability of this unexploited residue of the sugar cane industry, the filter cake could be used as a low cost raw material to obtain HA that show enhanced 
stable chemical feature and biological activity, confirmed by their effects on the PM H+-ATPase activity and root growth.

\section{References}

Anderson, J.M.; Ingram, J.S.I. 1993. Tropical Soil Biology and Fertility: A Handbook of Methods. CABI, Wallingford, UK. 221p.

Atiyeh, R.M.; Lee, C.A.; Edwards, C.A.; Arancon, N.Q.; Metzger, J.D. 2002. The influence of humic acids derived from earthwormprocessed organic wastes on plant growth. Bioresource Technology 84: 7-14.

Baes, A.U.; Bloom, P.R. 1989. Diffuse reflectance and transmition fourier transform infrared (DRIFT) spectroscopy of humic and fulvic acids. Soil Science Society of America Journal 53: 695-700.

Bloom, P.R.; Leenheer, J.A. 1989. Vibrational, electronic, and high-energy spectroscopic methods for characterizing humic substances. p.410-446. In: Hayes, M.H.B.; McCarthy, P.; Malcolm, R.L.; Swift, R.S., eds. Humic substances: in search of structure. Jonh Wiley, New York, NY, USA.

Bradford, M.M. 1976. A rapid and sensitive method for the quantification of micrograms quantities of protein utilizing the principle of protein-dye binding. Analytical Biochemistry 72: 248-254.

Camargo, F.A.O.; Santos, G.A.; Guerra, J.G.M. 1999. Macromoléculas e substâncias húmicas. p. 27-37. In: Santos, G.A.; Camargo, F.A.O., eds. Fundamentos da matéria orgânica: ecossistemas tropicais e subtropicais. Gênesis, Porto Alegre, RS, Brazil.

Campitelli, P.A.; Velasco, M.I.; Ceppi, S.B. 2006. Chemical and physicochemical characteristics of humic acids extracted from compost, soil and amended soil. Talanta 69: 1234-1239.

Canellas, L.P.; Baldotto, M.A.; Busato, J.G.; Marciano, C.R.; Menezes, S.C.; Silva, N.M.; Rumjanek, V.M.; Velloso, A.C.X.; Martin-Neto, L.; Simões, M.L. 2007. Estoque e qualidade da matéria orgânica de um solo cultivado com cana-de-açúcar por longo tempo. Revista Brasileira de Ciência do Solo 31: 331-340.

Canellas, L.P.; Espindola, J.A.A.; Rezende, C.E.; Camargo, P.B.; Zandonadi, D.B.; Rumjanek, V.M.; Guerra, J.G.M.; Teixeira, M.G.; Braz-Filho, R. 2004. Organic matter quality in a soil cultivated with perennial herbaceous legumes. Scientia Agrícola 61: 53-61.

Canellas, L.P.; Façanha, A.O.; Olivares, F.L.; Façanha, A.R. 2002. Humic acids isoled from earthworm compost enhance root elongation lateral root emergence, and plasma membrane $\mathrm{H}^{+}$ATPase activity in maize roots. Plant Physiology 130: 19511957.

Canellas, L.P.; Santos, G.A.; Rumjanek, V.M.; Moraes, A.A.; Guridi, F. 2001. Distribuição da matéria orgânica e características de ácidos húmicos em solos com adição de resíduos de origem urbana. Pesquisa Agropecuária Brasileira 36: 1529-1538.

Capriel, P.; Beck, T.; Borchert, H.; Harter, P. 1990. Relationship between soil aliphatic fraction extracted with supercritical hexane, soil microbial biomass and soil aggregate stability. Soil Science Society of America Journal 54: 415-420.

Celi, L.; Schnitzer, M.; Negre, M. 1997. Analysis of carboxyl groups in soil humic acids by wet method, fourier-transform infrared spectrophotometry, and solute-state carbon 13 nuclear magnetic resonance. A comparative study. Soil Science 162: 189-197.

Chen, Y.; Senesi, N.; Schnitzer, M. 1977. Information provided on humic substances by $E_{4} / E_{6}$ rations. Soil Science Society of America Journal 41: 352-358.

Colthup, N.B.; Daly, L.H.; Wiberley, S.E. 1964. Introduction to Infrared and Raman Spectroscopy. Academic Press, New York, NY, USA. 511p.
De Michelis, M.I.; Spanswick, R.M. 1986. $\mathrm{H}^{+}$-pumping driven by vanadate sensitive ATPase in membrane vesicles from corn roots. Plant Physiology 81: 542-547.

Demattê, J.A.M.; Silva, M.L.S.; Rocha, G.C.; Carvalho, L.A.; Formaggio, A.R.; Firme, L.P. 2005. Variações espectrais em solos submetidos à aplicação de torta de filtro. Revista Brasileira de Ciência do Solo 29: 317-326.

Dobbss, L.B.; Medici, L.O.; Peres, L.E.P.; Pino-Nunes, L.E.; Rumjanek, V.M.; Façanha, A.R.; Canellas, L.P. 2007. Changes in root development of Arabidopsis promoted by organic matter from oxisols. Annals of Applied Biology 151: 199-211.

Empresa Brasileira de Pesquisa Agropecuária [EMBRAPA]. 1997. Manual de Métodos de Análises de Solo. 2ed. EMBRAPA/ CNPS, Rio de Janeiro, RJ, Brazil. 212p.

Façanha, A.R.; De Meis, L. 1995. Inhibition of maize root $\mathrm{H}^{+}$. ATPase by fluoride and fluoroaluminate complexes. Plant Physiology 108: 241-246.

Façanha, A.R.; Olivares, F.L.; Velloso, A.C.X.; Braz-Filho, R.; Santos, G.A.; Canellas, L.P. 2002. Bioatividade de ácidos húmicos: efeitos sobre o desenvolvimento de prótons. Pesquisa Agropecuária Brasileira 37: 1301-1310.

Fiske, C.F.; Subbarow, Y. 1925. The colorimetric determination of phosphorus. Journal of Biological Chemistry 66: 375-383.

Frías, I.; Caldeira, M.T.; Perez, C.J.R.; Navarro, A.J.P.; Culianez, M.F.A.; Kuppinger, O.; stransky, H.; Pages, M.; Hager, A.; Serrano, R. 1996. A major isoform of the maize plasma membrane $\mathrm{H}^{+}$-ATPase: Characterization and induction by auxin in coleoptiles. Plant Cell 8: 1533-1544.

Griffth, S.M.; Schnitzer, M. 1975. Analytical characteristics of humic and fulvic acids extracted from tropical volcanic soils. Soil Science Society of America Journal 39: .861-867.

Hager, A.; Debus, G.; Edel, H.G.; Stransky, H.; serrano, R. 1991. Auxin induces exocytosis and rapid synthesis of a high-turnover pool of plasma-membrane $\mathrm{H}^{+}$-ATPase. Planta 185: 527-537.

Kononova, M.M. 1961. Soil Organic Matter: Its Nature, Its Role in Soil Formation and in Soil Fertility. Pergamon Press, New York, NY, USA. 450p.

Malik, K.A.; Azam, F. 1985. Effect of humic acid on wheat (Triticum aestivum L.) seedling growth. Environmental and Experimental Botany 25: 245-252.

Mbagwu, J.S.C.; Piccolo, A. 1998. Water-dispersible clay in aggregates of forest and cultivated soils in southern Nigeria in relation to organic matter constituents. p.71-83. In: Bergström, L.; Kirchman, L., eds. Carbon and nutrient dynamics in tropical agricultural ecosystems. CABI, Wallingford, UK.

Meunchang, S.; Panichsakpatanaa, S.; Weaver, R.W. 2005. Cocomposting of filter cake and bagasse: by-products from a sugar mill. Bioresource Technology 96: 437-442.

O'Donnell, R.W. 1973. The auxin-lke effects of humic preparations from leonardite. Soil Science 116: 106-112.

Piccolo, A. 2002. The supramolecular structure of humic substances: a novel understanding of humus chemistry and implications in soil science. Advances in Agronomy 75: 57-133.

Piccolo, A.; Mbagwu, J.S.C. 1999. Role of hydrophobic components of soil organic matter on soil aggregate stability. Soil Science of America Journal 63: 1801-1810.

Piccolo, A.; Nardi, S.; Concheri, G. 1996. Macromolecular changes in humic substances induced by interaction with organic acids. European Journal of Soil Science 47: 319-328.

Plaza, C.; Senesi, N.; Polo, A.; Brunetti, G. 2005. Acid-Base properties of humic and fulvic acids formed during composting. Environmental Science and Technology 39: 7141-7146.

Quaggiotti, S.; Ruperti, B.; Pizzeghello, D.; Francioso, O.; Tugnoli, V.; Nardi, S. 2004. Effect of low molecular size humic substances on nitrate uptake and expression of genes involved in nitrate transport in maize (Zea mays L.). Journal of Experimental Botany 55: 803-813.

Rice, J.A.; MacCarthy, P. 1991. Statistical evaluation of the elemental composition of humic substances. Organic Geochemistry 17: 635-648. 
Rodda, M.R.C.; Canellas, L.P.; Façanha, A.R.; Zandonadi, D.B.; Guerra, J.G.M.; Almeida, D.L.; Santos, G.A. 2006. Improving lettuce seedling root growth and ATP hidrolysis with humates from vermicompost. I. Effect of vermicompost concentration. Revista Brasileira de Ciência do Solo 30: 649-656.

Saab, S.C.; Martin-Neto, L. 2007. Anéis aromáticos condensados e relação $\mathrm{E}_{4} / \mathrm{E}_{6}$ de ácidos húmicos de gleissolos por $\mathrm{RMN}$ de ${ }^{13} \mathrm{C}$ no estado sólido utilizando a técnica $\mathrm{CP} / \mathrm{MAS}$ desacoplamento defasado. Química Nova 30: 260-263.

Saiz-Jimenez, C.; Hermosin, B.; Trubetskaya, O.E.; Reznikova, O.I.; Afanas'eva, G.V.; Trubetskoj, O.A. 2006. Thermochemolysis of genetically different soil humic acids and their fractions obtained by tandem size exclusion chromatography-polyacrylamide gel electrophoresis. Geoderma 131: 22-32.

Schnitzer, M.; Gupta, U.C. 1965. Determination of acidity in soil organic matter. Soil Science of America Proccedings 29: 274277.

Serrano, R. 1989. Structure and function of plasma membrane ATPase. Annual Review of Plant Physiology and Plant Molecular Biology 40: 61-94.

Spaccini, R.; Piccolo, A.; Conte, P.; Haberhauer, G.; Gerzabek, M.H. 2002. Increased soil organic carbon sequestration through hydrophobic protection by humic substances. Soil Biology and Biochemistry 34: 1839-1851.

Stevenson, F.J. 1994. Humus Chemistry: Genesis, Composition, Reactions. John Wiley, New York, NY, USA. 496p.

Sze, H. 1985. $\mathrm{H}^{+}$- translocating ATPase: advances using membrane vesicles. Annual Review of Plant Physiology and Plant Molecular Biology 36: 175-208.
Sze, H.; Li, X.; Palmgren, M.G. 1999. Energization on plant cell membranes by $\mathrm{H}^{+}$-Pumping ATPases: regulation and biosyntesis. Plant Cell 11: 677-689.

Vaughan, D.A. 1974. Possible mechanisms for humic acid action on cell elongation in root segments of Pisum sativum under aseptic condictions. Soil Biology Biochemistry 6: 241-247.

Vaughan, D.A.; Malcolm, R.E. 1985. Influence of humic substances on growth and physiological processes. p. 37-75. In: Vaughan, D.; Malcolm, R.E., eds. Soil organic matter and biological activity. Martinus-Nijhoff, Boston, MA, USA.

Veiga, C.F.M.; Vieira, J.R.; Morgado, I.F. 2006. Diagnóstico da Cadeia Produtiva da Cana-de-Açúcar do Estado do Rio de Janeiro: Relatório de Pesquisa. FAERJ/SEBRAE. Rio de Janeiro, RJ, Brazil. 107p.

Zandonadi, D.B.; Canellas, L.P.; Façanha, A.R. 2007. Indolacetic and humic acids induce lateral root development through a concerted plasmalemma and tonoplast $\mathrm{H}^{+}$pumps activation. Planta 225: 1583-1595.

Zech, W.; Senesi, N.; Guggenberger, G.; Kaiser, K.; Lehmann, J.; Miano, T.M.; Miltner, A.; Schroth, G. 1997. Factors controlling humification and mineralization of soil organic matter in the tropics. Geoderma 79: 117-161.

Received December 19, 2008

Accepted October 07, 2009 